\section{Closing the gap between Business Networks and Value Chain Analysis}

\author{
Luis Oliveira ${ }^{1}$ \\ Afonso Fleury ${ }^{1}$ \\ 1 University of São Paulo, Production Engineering \\ Department, São Paulo, Brazil \\ Maria Tereza Fleury ${ }^{2}$ \\ ${ }^{2}$ Fundação Getúlio Vargas, Sao Paulo School of Business \\ Administration, São Paulo, Brazil
}

Received on $12 / 19 / 2017$

Approved on

01/16/2019

Responsible editor:

Prof. Dr. João Maurício Gama

Boaventura

Evaluation process:

Double Blind Review

\begin{abstract}
Purpose - The study discusses alternative ways to bridge the gap between global value chain literature and literature focused on management and strategy in business networks.
\end{abstract}

Design/methodology/approach - The study builds on an article cocitation analysis using bibliographic data from 762 papers retrieved from selected journals.

Findings - The results highlight influential constructs and frameworks originating in the business network literature that could leverage the research on Global Value Chains.

Originality/value - By better connecting with business network research, global value chain theory may improve its capacity to cope with modern empirical challenges, overcome criticisms, and communicate better with mainstream disciplines.

Keywords - Business Networks; Value Chain Governance; Bibliometry \title{
4
}




\section{Introduction}

With longstanding roots in the worldsystems literature, GVC theory had matured and assumed its current formats by the mid1990s (Bair, 2005, 2008). "The GVC framework allows one to understand how global industries are organized by examining the structure and dynamics of different actors involved in a given industry" (Gereffi \& Fernandez-Stark, 2011, p. $2)$. Its relevance resides precisely in its capacity to accommodate issues that demand attention in the modern global order, which is marked by growing economic interdependence and increasing dispersion of economic activities across borders (Nayyar, 2003, p. 39). Over time, GVC theory has gradually transitioned from macro-level debates, mostly shaped by developmentalist concerns, to a research agenda that also incorporates micro-level issues such as firm strategy (Gereffi, 2014a). In spite of this, concepts and constructs which could be useful to such an agenda and have already been studied in the business network literature remain underexplored in GVC research (Sako \& Zylberberg, 2017).

Since its early days, GVC theory has developed away from mainstream management research, drawing instead on a rich background encompassing international economics, sociology, political economy, and studies of clusters and industries (Bair, 2005; Morrison, Pietrobelli, \& Rabellotti, 2008). With such a background, GVC theory has evolved mostly around two complementary concepts: governance and upgrading. The former is related to top-down dynamics that focused on powerful firms in the chain and on the organization of global industries, while the latter gives rise to strategies that economic actors can use to achieve better positions in the value generation process (Gereffi, 1999; Gereffi \& Lee, 2012; Morrison et al., 2008; Ponte \& Sturgeon, 2014). The governance concept usually receives more attention because of its utility in discussing how firms are included in or excluded from GVCs, and its importance in shaping upgrading opportunities (Gereffi, 2014b; Ponte \& Sturgeon, 2014).

Pending issues create a pressing need to advance the connection between GVC and business network research. For instance, GVC theory is recurrently criticized for privileging linear dynamics over network analyses, despite GVC authors defending their chain metaphor as being a useful simplification of reality (e.g., Coe, Dicken, \& Hess, 2008; Henderson, Dicken, Hess, Coe, \& Yeung, 2002; Yeung \& Coe, 2015). With the evolution of digitalization and ecosystem-based industries, studies of modern firms require theoretical frameworks capable of capturing phenomena that occur at the network level - and which could be ignored or difficult to grasp within linear relationships (Jacobides, Cennamo, \& Gawer, 2018; Möller \& Halinen, 2017). Moreover, GVC theory's treatment of concepts such as governance, power, upgrading, and value may come across barriers to entry in mainstream journals if it does not connect with conventional management and strategy theories. In fact, GVC theory is already isolated from the main management journal outlets (Sako \& Zylberberg, 2015).

By visiting business network research, GVC theory could improve its capacity to cope with modern empirical challenges, communicate better with scholars from mainstream disciplines, and establish smoother connections with alternative network-based frameworks. Moreover, an improved connection between GVC theory and network research may unveil possibilities for leveraging the multi-level nature of business network theory in studies of GVC-related phenomena, thus opening up a way to formally connect macro-level issues (such as national policy-making and industry-level dynamics) with those at the micro-level (such as firm strategy and consumer behavior) (Zaheer, Gözübüyük, \& Milanov, 2010). We aim to contribute to this conversation by discussing alternative ways to bridge the gap between the GVC literature and the literature focused on business 
network management and strategy. Our research question is: How could business network research contribute to the advancement of GVC research, in particular the debate about GVC governance?

We address our question with a bibliometric analysis of the management and strategy research on business networks and by discussing possible contributions to the GVC literature, with a focus on GVC governance. We use the typology that Provan et al. (2007) put forward for the organization of business network research to make the connections between the outcomes of the bibliometric analysis and the GVC literature, identifying which communities of business network scholars have developed knowledge that is relevant to the different branches of GVC research, thus disclosing conceptual bridges.

After this introduction, we review the literature on GVCs and GVC governance, followed by an assessment of how the literature on business networks may be associated with the dimensions of GVC governance. Methodological concerns are discussed in the following section, after which we illustrate the connection between the research on business networks and GVC governance with an example of how the former can inject dynamism into the latter.

\section{Theoretical Background}

\section{I GVC governance and network dynamics in GVC research}

The GVC literature adopts the chain metaphor as an intentional simplification and systematization of empirical network processes (Sturgeon, Biesebroeck, \& Gereff, 2008). The chain metaphor enables a focus on sequences of value-added processes while preserving awareness of their broader institutional and industrial contexts, as well as the existence of various external sources of critical resources (Sturgeon, 2001). This metaphor was already present in Gereffi's (1994) conceptualization of the governance of what he still called "commodity chains", identifying governance as the "authority and power relationships that determine how financial, material, and human resources are allocated and flow within a chain" (p. 94). Drawing attention to the firms holding the most powerful positions in their chains (the so-called "lead firms"), Gereffi distinguished between "producer-driven" and "buyer-driven" chains, depending on whether the lead firms' power was associated with production or design/marketing capabilities, respectively. Because of its focus on global buyers' capacity to dictate the direction of entire chains, Gibbon, Bair, and Ponte (2008) called Gereffi's (1994) approach to governance "governance as driving". Limitations in the producer- and buyerdriven categories, coupled with the increasing importance of chains led by global buyers, soon required new interpretations of the concept of governance. At that time, the emergence of alternative network- and chain-based frameworks also led the research community to adopt "Global Value Chains" as the most inclusive label to represent "the relative value of those activities that are required to bring a product or service from conception through the different phases of production (...), delivery to final consumers, and final disposal after use" (Gereffi, Humphrey, Kaplinsky, \& Sturgeon, 2001, p. 3). Gereffi, Humphrey, and Sturgeon (2005) acknowledged that value chains may exhibit a broad range of network forms, varying according to suppliers' capabilities and the complexity and codifiability of transactions. Represented as a continuum between market and hierarchies, modular networks operate based on standards and codification, while relational ones rely on trust and reputation, and those of the captive type depend on lead firms' buying power (Ponte \& Sturgeon, 2014).

Given that Gereffi et al.'s (2005) typology focuses on attributes of specific value chain linkages to better explain variations in the structure of network forms, it is called "governance as coordination" (Gibbon et al., 2008). The 2005 governance typology is often associated with transaction costs economics, 
but in fact it constituted a multidisciplinary effort combining "transaction costs economics, production networks, and technological capability and firm-level learning" (Gereffi et al., 2005, p. 78). It established a dialogue between economic and social arguments, outlining conditions for the use of particular coordination mechanisms to facilitate exchanges between value chain members (Bair, 2008). The locus of power for exercising such coordination is derived from firms' strategic capabilities (whether related to marketing/design or production expertise), their control over distribution channels, and their scale economies, for instance (Gereffi, 1994; Sturgeon, 2009).

Besides governance as driving and coordination, a perspective of "governance as normalizing" has been defended to explain the role of standards and norms in enabling aggregate GVC governance dynamics (Gibbon et al., 2008; Ponte \& Sturgeon, 2014). According to this perspective, the governance of whole value chains/networks is affected by commonly agreed norms and conventions that promote alignment across the different linkages of these value chains/networks (Ponte \& Gibbon, 2005; Ponte \& Sturgeon, 2014). These norms or conventions imply different criteria for dealing with uncertainty in interfirm exchanges, with different transmission potential along value chains. The "governance as normalizing" approach is rooted in Convention Theory, whose arguments are close to neo-institutional economics and focus on the common language adopted by market participants to qualify products' attributes in contexts of information asymmetry (Bazzoli, Kirat, \& Villeval, 1994; Raikes, Jensen, \& Ponte, 2000).

Altogether, the evolution of the GVC literature has been driven by empirically rich studies seeking explanations for the systemic industrial reality that followed globalization. However, in GVC research, business networks represent more an empirical context than an object of theoretical development, as is evident in the preservation of the chain metaphor. Fields such as management and strategy, on the other hand, feature richer traditions in the discussion of business networks as an object of study. This understanding outlines underlying contributions to be explored within GVC research.

\subsection{Connecting GVC literature with inter-organizational network research}

According to Borgatti and Foster (2003), the volume of research adopting network lenses has grown exponentially since the second half of the 20th century and, since the 1990s, networks can be found in "virtually every traditional area of organizational scholarship" (p. 1005). This research not only exhibits a highly diversified theoretical background, but can also feature multiple levels of analyses, including actor, dyad, and network levels (Zaheer et al., 2010). While it may be difficult to situate network research within one exclusive theoretical domain, Provan et al. (2007) advanced a typology that provides a neat perspective on the distinct approaches identifiable in the field. For them, network research can be segmented according to the use of organizational or relational/network variables as theoretical inputs and the focus on outcomes at the level of individual firms or groups of actors (Table 1).

Provan et al.'s (2007) typology is useful for identifying which body of network research may have more affinity with the various strands of GVC literature, considering parallels based on the empirical scope identified in each cell of Table 1. Firstly, Gereffi's (1994) approach to governance as driving seems to fit the discourse of cell 4. The research represented by this cell tries to explain "how individual organizations and their actions might affect outcomes at the network level, such as network structures, stability, and effectiveness" (Provan et al., 2007, p. 483). Similarly, governance as driving focuses on how lead firms use their power to shape suppliers' behavior with performance criteria in terms of price, quality, and delivery standards (Lee \& Gereffi, 2015). This perspective supports viewing 
lead firms as being responsible for "defining the terms of supply-chain membership", as well as determining "where, when, and by whom value is added" (Ponte \& Sturgeon, 2014, p. 201).

Table 1

Typology of business network research

\begin{tabular}{lll}
\hline \multirow{2}{*}{ Input focus } & \multicolumn{2}{c}{ Outcome focus } \\
\cline { 2 - 3 } Firm-level & Individual firms & Groups of actors \\
\hline Relational- or Network-level & 1. Impacts of firms on dyadic partners & 4. Impacts of hub firms on their networks \\
\hline
\end{tabular}

Note. Source: Adapted from "Interorganizational Networks at the Network Level: A Review of the Empirical Literature on Whole Networks," by K. G. Provan, A. Fish, and J. Sydow, 2007, Journal of Management, 33, p. 483.

Unlike Gereffi's (1994) approach, Gereffi et al.'s (2005) view of "governance as coordination" is a "theory of linkages" (Ponte \& Sturgeon, 2014, p. 206). It focuses on lead firms' makeor-buy decisions, outlining conditions for their preference for using standards, relational trust, or their buying power to coordinate transactions with other network participants (Bair, 2008; Ponte \& Sturgeon, 2014). The features of "governance as coordination" relate it to the dyadic debates of cell 1, which encompasses explanations for interfirm relationships that focus on "such issues as organizational trust to explain the nature and extent of an organization's involvement with others" (Provan et al., 2007, p. 483).

The "normalizing" view of governance, in turn, adopts a third perspective by focusing on socially legitimized coordination mechanisms and entire networks (Ponte \& Sturgeon, 2014). It refers to the standards and norms that shape GVC participation and upgrading, which allow for the transmission of commonly agreed elements of coordination along the chain (Lee \& Gereffi, 2015; Ponte \& Gibbon, 2005). "Governance as normalizing" can thus be related to cell 3, which includes studies that examine the whole network and addresses "the impact of multilevel actions and structures on network-level outcomes" (Provan et al., 2007, p. 483). For instance, the research in cell 3 unveils "how networks evolve, how they are governed, and, ultimately, how collective outcomes might be generated" (ibid, p. 480).

No formulation of GVC governance is directly related to cell 2 of Table 1 , which features theories that explore "the impact of networklevel structures and behaviors on individual organizations" (Provan et al., 2007, p. 483). In fact, the various perspectives of GVC governance adopt the viewpoint of actors that hold enough power to influence and not be influenced. Yet, studies of GVC governance often also address the viewpoint of the less powerful firms participating in chains and networks, reflecting the consequences of governance for them in the idea of upgrading (e.g. Gereffi, 1999; Humphrey \& Schmitz, 2002; Navas-Alemán, 2011). Besides explaining how power is used, one of the uses of the GVC governance literature is to address firm-level outcomes of its use, such as in: firms' access to value creation and capture activities; their inclusion and exclusion in the chain; and the economic and social effects of their GVC participation (Ponte \& Sturgeon, 2014). In light of these aforementioned arguments, Table 2 uses Provan et al.'s (2007) typology to indicate our expectations for connecting GVC and network research. 
Table 2

Parallels between the GVC literature and the business network research

\begin{tabular}{lcc}
\hline & \multicolumn{2}{c}{ Outcome focus } \\
\cline { 2 - 3 } Input focus & Individual firms & Groups of actors \\
\hline Firm-level & $\bullet$ Governance as coordination of dyads & $\bullet$ Governance as driving chains and networks \\
\hline Relational- or Network-level & $\bullet$ GVC upgrading & $\bullet$ Governance as normalizing \\
\hline
\end{tabular}

Note. Source: Elaborated by the authors and matching the evolution of the literature on GVC governance with Provan et al.'s (2007) typology for the business network research.

With this mapping of the GVC literature in Provan et al.'s (2007) typology, its various strands can be connected with network research if this, in turn, can also be related to the cells of Table 1 in a systematized way. In fact, the typology in Table 1 only organizes network research generically according to its empirical focus, but each of its cells feature multiple theories that need to be identified. Identifying these theories will allow for better substantiation of the connections between GVC and network research, thus building on the parallels of Table 2. To quote Salancik (1995): "to be productive in understanding organizations, network analysts will need to become more theoretical about the things they study" (p. 348). Hence, we first focus our analysis on mapping the theoretical structure of business network research, particularly in management and strategy, in order to later advance the discussion of Table 2 .

\section{Methods}

\section{I Research design}

The main options for mapping publications in a research domain are citation analysis, cocitation analysis, and bibliographical coupling (Zupic \& Čater, 2015). Citation analyses are rarely used to visualize the organization of scientific fields because they often yield very sparse networks, reflecting only direct citations (Eck \& Waltman, 2014). Bibliographical coupling, or the analysis of the references shared between publications, is biased by the fact that its object of analysis (the references listed in documents) is static over time and is produced by the very authors of the documents under focus (Zupic \& Čater, 2015). Although bibliographical coupling can still be useful to capture citation habits within limited timeframes, such as when mapping the research front of a field, co-citation analyses represent a better choice for systematizing the historical importance and impact of documents that the academic community chooses to cite (Hjørland, 2013)but bibliometric techniques make it possible to identify candidate terms for thesauri and to organize knowledge by relating scientific papers and authors to each other and thereby indicating kinds of relatedness and semantic distance. It is therefore important to view bibliometric techniques as a family of approaches to $\mathrm{KO}$ in order to illustrate their relative strengths and weaknesses. The subfield of bibliometrics concerned with citation analysis forms a distinct approach to $\mathrm{KO}$ which is characterized by its social, historical and dynamic nature, its close dependence on scholarly literature and its explicit kind of literary warrant. The two main methods, co-citation analysis and bibliographic coupling represent different things and thus neither can be considered superior for all purposes. The main difference between traditional knowledge organization systems (KOSs. Two documents are "co-cited" when a third one cites both of them, which is assumed to suggest similarities between the content of those documents (Eck \& Waltman, 2014; Zupic \& Čater, 2015). Therefore, we map the intellectual structure of the business network research with an article co-citation analysis of the management and strategy fields, aiming to substantiate the links between the GVC and network literature established in Table 2. 
Based on similarities among publications, co-citation analyses reflect the existence of research streams in a given field in the form of clusters of closely-related contributions grouped in visual maps (or "bibliometric networks") (Small, 1999). We produced our co-citation networks by processing our bibliographic data in VOS Viewer (v. 1.6.6), which is a freely-available software package dedicated to the graphical representation of bibliographic maps (Eck \& Waltman, 2010). The output of co-citation analyses in VOS Viewer is a bibliometric network whose nodes represent documents cited by articles in our sample, while links between nodes exist when they are cited together by any paper retrieved in our search. The nodes of these networks are automatically assigned to clusters by VOS Viewer, which differs from alternative visualization tools as it relies on a unified algorithm to both build the network representation of bibliometric analyses and group nodes around clusters (Waltman, Eck, \& Noyons, 2010). VOS Viewer's algorithm builds on the VOS mapping technique, which maximizes the similarity between nodes by minimizing a weighted sum of squared Euclidean distances between all pairs of nodes (Eck, Waltman, Dekker, $\&$ van den Berg, 2010).

\subsection{Data collection}

We started our investigation by searching Web of Science for all articles related to business networks published in the business and management categories. In line with the diversity of terms adopted to address business networks, we used "cooperation", "network*", "interorganizational network*", "consortia", "cluster*", and "alliance*" as alternative topic keywords in our search. Such keywords were inspired by terms that Provan et al. (2007) and Todeva and Knoke (2005) list as possible forms of interorganizational relationships that configure networks. Recognizing that the modern shapes of the GVC literature are often traced back to Gereffi's (1994) chapter about the commodity chains of large US retailers and the concept of governance, we limited our search to papers published since 1994. The study of networks is actually older than that, but this threshold allows us to focus on a body of research produced under the same context of globalization that has been driving the development of modern GVC literature.

After that, we narrowed our sample down to papers published in Academy of Management Journal (AMJ), Academy of Management Review (AMR), and Strategic Management Journal $(\mathrm{SMJ})$, which we selected due to their flagship role in the fields of management and strategy. We identified these journals from the list published by Scimago Journal Ranking under the category "Strategy and Management", also following recommendations from knowledgeable colleagues and our own judgment. By focusing on those sources, we expected to cover the potentially more influential research on the topic we were investigating, using a more efficient method. Indeed, those three journals together account for $72.2 \%$ of the papers selected by Lima and Campos (2009) for a literature review of studies on strategic alliances and networks published between 1997 and 2007. We performed our search in early November 2017 and retrieved 762 papers.

We proceeded to the co-citation analysis by feeding our sample of articles into VOS Viewer. We narrowed the software's graphic output down to the 100 articles most cited by papers in our sample, which represent all documents featuring at least 34 citations. That threshold was chosen after testing different possibilities, since the resulting representation should report a comprehensive overview of the investigated field but still allow for useful aggregate analyses (Zupic \& Čater, 2015). Moreover, we still obtained networks with fairly similar configurations of clusters when using thresholds as low as 15 citations (379 articles).

\subsection{Descriptive analysis}

Overall, the yearly distribution of the sampled papers (Figure 1) follows an upwards 
trend that reveals a growing interest in the business network research in the selected journals. Even though 2017 seems to anticipate a low number of papers compared to 2016, Figure 1 apparently exhibits peaks of publications following cycles of five or six years $(2000,2005,2011)$. If the next few years reproduce this cycle, this represents a trend worth exploring.

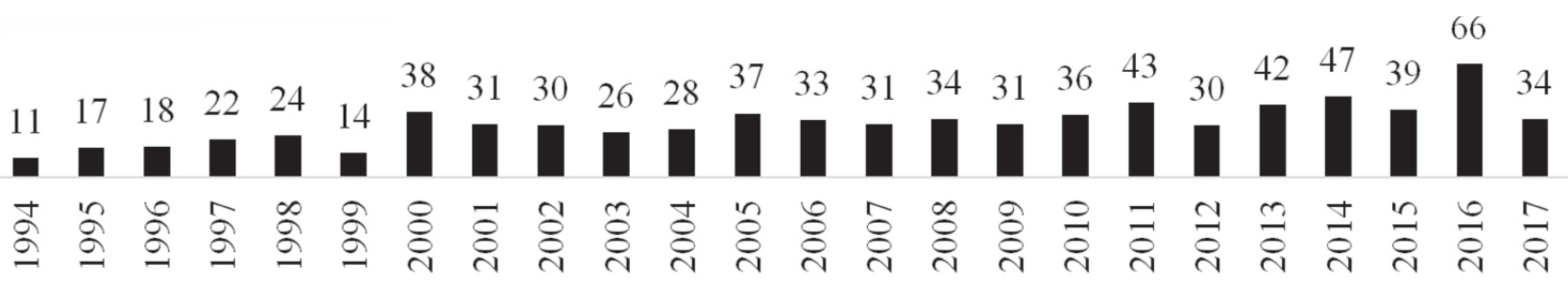

Figure 1. Yearly distribution of the sampled papers

Regarding the distribution of papers among the selected journals (Table 3), there is a clear concentration of publications in SMJ. That journal holds more than half of the papers in our sample, followed by around one third in AMJ and one tenth in AMR. This distribution does not follow Scimago's journal ranking (which features AMJ followed by AMR, and then SMJ), but is close to the proportion found by Lima and Campos Filho (2009) among those journals. This could be evidence of the status of business network research within the fields of management and strategy, but also a sign of the wideness of these journals' scopes.

Table 3

\section{Distribution of publications among the selected journals}

\begin{tabular}{lcc}
\hline Journal & Number of articles & \% of Articles \\
\hline Strategic Management Journal & 414 & $54.3 \%$ \\
Academy of Management Journal & 260 & $34.1 \%$ \\
Academy of Management Review & 88 & $11.5 \%$ \\
\hline Total & $\mathbf{7 6 2}$ & $\mathbf{1 0 0 . 0 \%}$ \\
\hline
\end{tabular}

Finally, the sample we retrieved is highly dispersed. Only four scholars appear as first authors in at least five papers (Reuer, J. J., 11; Luo, Y. D., 8; Schilling, M.A., 5; Steensma, H.K., 5), while another 583 scholars are first authors of between one and four papers. Besides that, 13 articles accumulate at least 1,000 citations each (76.7 citations/year, on average), led by Szulanski's (1996) paper with 2,849 total citations (or 129.5 citations/year). The average total citations for the remaining 749 papers is 122.7 (or 9.1 citations/year).

\section{Article Co-Citation Analysis}

The article co-citation network derived from our sample of papers appears in Figure 2, which uses shades of gray to identify four clusters automatically grouped by VOS Viewer. In order to make their identification easier, we highlighted their location with dashed lines. The nodes' sizes are proportional to the number of times that our sampled papers cited these nodes, whereas the linkages' thickness depends on the number of papers citing each pair of documents together. Altogether, Figure 2 provides an overview of the 
knowledge structure of business network research in the management and strategy fields, which will be later used to establish parallels with GVC research, drawing on the connections suggested in Table 2.

The nodes in each cluster of Figure 2 exhibit different levels of relevance, with the most important representing leading research topics in their respective groups. Different measures attest the relevance of nodes in a bibliometric network, among which the most used ones are closeness, betweenness, degree, and eigenvector centralities (Yan \& Ding, 2009). Nodes with high closeness have multiple connections relying on few intermediaries, while those with high betweenness intermediate in more pairs of nodes. Even though these two measures are useful to understand the role of nodes in the overall network structure (such as being a hub of information), they provide limited information about their influential capacity. Degree and eigenvector, in turn, are better suited for mapping leading nodes in bibliometric networks and their clusters. The former measure ranks nodes according to the number of linkages, while the latter associates nodes' relevance with the relevance of their neighbors. Nodes with high eigenvectors may not be the most connected ones but will have the best connections, which constitutes a better indicator of status (Bonacich, 2007)and the related centrality measure Bonacich's c(lu03b2. Hence, we use eigenvector centralities to rank the nodes in Figure 2 and identify the ones leading the debate of each cluster (Table 4).

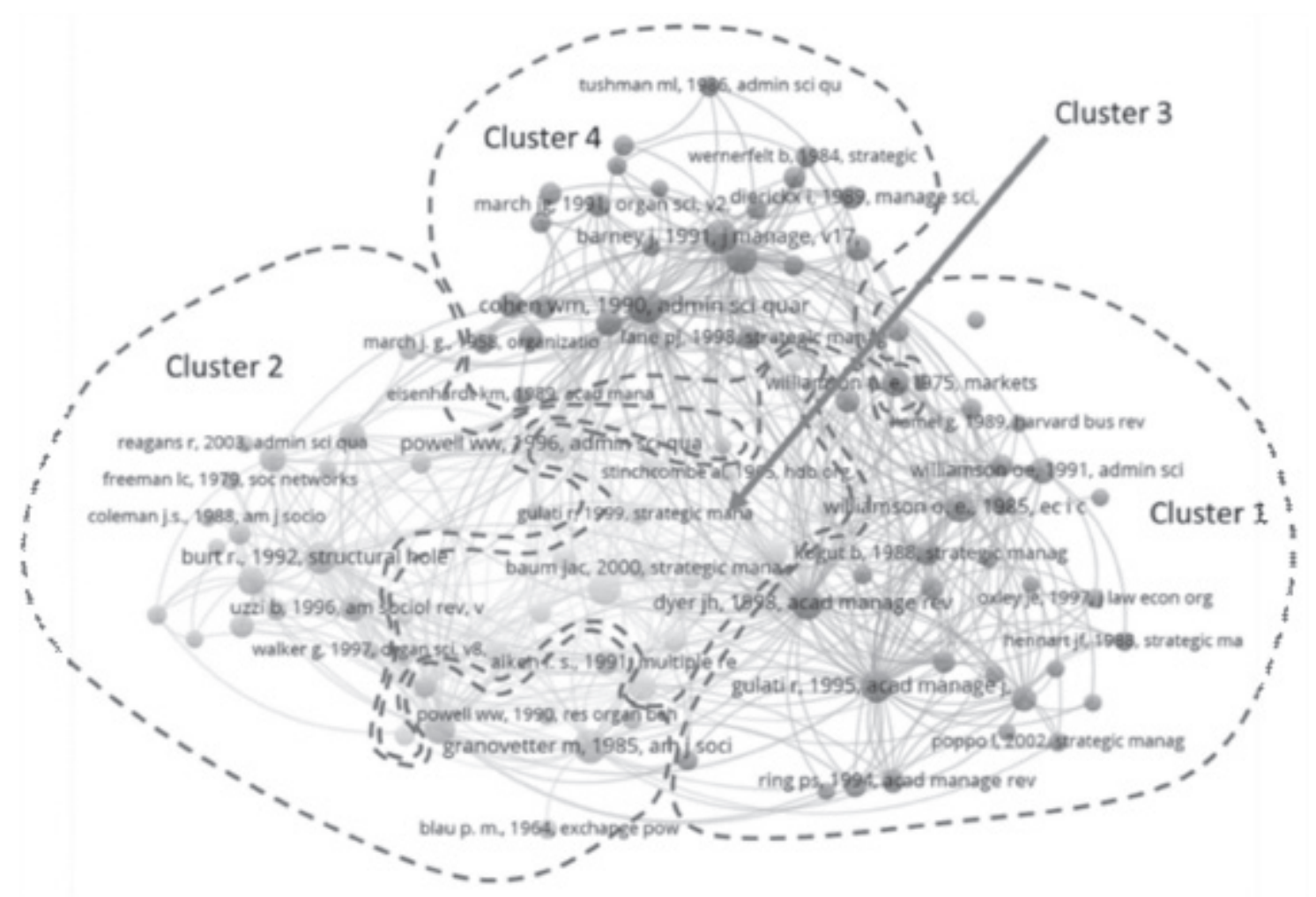

Figure 2. Article co-citation network

Based on its leading documents, Cluster 1 focuses on the dynamics of dyadic relationships. Williamson's (1985) book on Transaction Costs Theory (TCT) is the one with the smallest centrality, thus representing the mainstream economic perspective for which other authors discuss alternative views. The most central paper is Dyer and Singh (1998), which bridges social 
and economic arguments in a relational view of resources and routines in dyads. The evaluation of arguments that present alternatives to economic views is also present in Gulati's (1995a) analysis of trust in alliances and in Kogut's (1988) explanations of Joint Ventures. Organizational learning is one of the alternative lenses considered by Kogut and is further explored by Mowery, Oxley, and Silverman (1996) within interfirm knowledge transfers.

Leading papers in Cluster 2 address the impact of business networks on individual firms. Its central piece is provided by Granovetter's (1985) defense of network relationships' role in promoting trust and constraining economic actors. Such effects would make it impossible to understand economic actors' behavior as independent of their social connections, characterizing what the author called "embeddedness". Uzzi (1996, 1997) discussed the formation of embedded network relationships and their relational effects on firm performance, while Burt (1992) explored a structural dimension of embeddedness in the benefits of bridging isolated network groups. Rowley, Behrens, and Krackhardt (2000) connected these ideas, asserting that both relational and structural embeddedness must be considered when explaining firm behavior and performance.

Table 4

\section{Leading articles in each cluster}

\begin{tabular}{|c|c|c|c|}
\hline Cluster & Theoretical approach & Leading papers & Eigenvector centrality \\
\hline \multirow[t]{5}{*}{1} & \multirow[t]{5}{*}{ Dynamics of dyadic relationships } & Dyer and Singh (1998) & 0.2170 \\
\hline & & Gulati (1995a) & 0.1940 \\
\hline & & Mowery, Oxley, and Silverman (1996) & 0.1350 \\
\hline & & Kogut (1988) & 0.1300 \\
\hline & & Williamson (1985) & 0.1280 \\
\hline \multirow[t]{5}{*}{2} & \multirow{5}{*}{$\begin{array}{l}\text { Impact of networks on individual } \\
\text { firms }\end{array}$} & Uzzi (1997) & 0.1740 \\
\hline & & Burt (1992) & 0.1650 \\
\hline & & Granovetter (1985) & 0.1630 \\
\hline & & Uzzi (1996) & 0.1350 \\
\hline & & Rowley et al. (2000) & 0.1220 \\
\hline \multirow[t]{11}{*}{3} & \multirow[t]{11}{*}{ Dynamics of alliance networks } & Powell, Koput, and Smith-Doerr (1996) & 0.1970 \\
\hline & & Gulati (1995b) & 0.1570 \\
\hline & & Gulati (1998)which has primarily considered alliances & 0.1540 \\
\hline & & as dyadic exchanges and paid less attention to the fact & 0.1460 \\
\hline & & that key precursors, processes, and outcomes associated & 0.1200 \\
\hline & & with alliances can be defined and shaped in important & \\
\hline & & ways by the social networks within which most firms are & \\
\hline & & embedded. It identifies five key issues for the study of & \\
\hline & & alliances: $(1$ & \\
\hline & & Pfeffer and Salancik (1978) & \\
\hline & & Baum, Calabrese, and Silverman (2000) & \\
\hline \multirow[t]{5}{*}{4} & \multirow[t]{5}{*}{ Focus on individual firms } & Cohen and Levinthal (1990) & 0.2020 \\
\hline & & Nelson and Winter (1982) & 0.1650 \\
\hline & & Barney (1991) & 0.1570 \\
\hline & & Kogut and Zander (1992) & 0.1310 \\
\hline & & Lane and Lubatkin (1998) & 0.1140 \\
\hline
\end{tabular}

The authors in Cluster 3 focus mostly on explaining the formation of alliance networks. Its most central paper is Powell, Koput, and SmithDoerr (1996), featuring a discussion of firms' propensity to enter alliances when knowledge and collaboration are central to competitive advantage. Also, Gulati (1995b) discussed alliance formation by contrasting embeddedness 
arguments and Resource Dependence Theory (RDT). RDT is in fact represented in this cluster by Pfeffer and Salancik's (1978) article, which is used as a counterpoint in the debates of Cluster 3 similarly to the role of Williamson's (1985) book in Cluster 1. According to Gulati (1995b), resource dependence does not explain alliance formation alone, but the social structure guiding firm behavior is also relevant in making firms alliance partners. In Cluster 3, the embedded context of alliances received attention from Gulati (1998)which has primarily considered alliances as dyadic exchanges and paid less attention to the fact that key precursors, processes, and outcomes associated with alliances can be defined and shaped in important ways by the social networks within which most firms are embedded. It identifies five key issues for the study of alliances: (1, while Baum et al. (2000) addressed performance feedback in alliance networks.

Finally, Cluster 4 diverges from the other ones due to its focus on individual firms, encompassing pillars of the Resource-Based View (RBV) and the Knowledge-Based View (KBV) of the firm. Nelson and Winter (1982) described firms as collections of routines that change continuously and are subject to natural selection mechanisms. According to Barney (1991), routines and other resources only provide firms with sustainable competitive advantages when they are considered valuable, rare, inimitable, and non-substitutable. Kogut and Zander (1992) built on such perspectives to characterize firms as entities whose competitive advantage is the creation and transfer of knowledge. The concept of absorptive capacity has become key to KBV and is explored by Cohen and Levinthal (1990) (the most central paper in this cluster) and Lane and Lubatkin (1998), representing firms' ability to recognize the value of new information, assimilate it, and successfully apply it.

Altogether, the association between leading papers in each cluster and reasonably welldefined research streams reinforces the validity of seeing Figure 2 as a co-citation network made of four clusters. The more recent dates of the leading papers in Clusters 1, 2, and 3 compared to Cluster 4 could suggest a transformation in the agenda of network research over time, but more precise inferences would demand additional analyses. In line with our research objectives, the next section discusses the outcomes of our author co-citation analysis under Provan et al.'s (2007) typology in order to explore the parallels between network research and GVC governance that we suggested in Table 2.

\section{Discussion}

The topics revealed in each cluster of Figure 2 can be connected to the scopes of network research foreseen in Provan et al.'s (2007) typology, from which point the associations between GVC and network literature in Table 2 can receive further elaboration (Table 5). Firstly, the research represented by Cluster 1 addresses the impacts of firms on other firms within dyadic relationships, which is included in the scope of cell 1 of Table 1 and finds parallels in the empirical focus of Gereffi et al.'s (2005) "governance as coordination" (see Table 2). Their theoretical approach is similar: the authors in Cluster 1 built a relational view of networks by bridging economic and social arguments similarly to how Gereffi and his colleagues discussed the adoption of varied coordination mechanisms in the value chain (Bair, 2008). While trust is important both in Gereffi et al.'s (2005) "governance as coordination" and in Cluster 1 (Dyer \& Singh, 1998; Gulati, 1995a), the research in this cluster supports advancing the perspective of GVC governance as an instrument for transferring tacit knowledge and technological capability (Kogut, 1988; Mowery et al., 1996). In fact, Gereffi et al. (2005) were aware of the learning benefits of relational governance mechanisms. Nevertheless, organizational learning lenses introduce organizational and cognitive mechanisms that extrapolate the makeor-buy decisions included in the "governance as coordination" typology (Kogut, 1988). 
Table 5

\section{Summary of findings}

\begin{tabular}{|c|c|c|c|c|}
\hline Cluster & Content of leading papers & $\begin{array}{l}\text { Type of network } \\
\text { research }\end{array}$ & $\begin{array}{c}\text { Associated dimension of GVC } \\
\text { governance }\end{array}$ & $\begin{array}{l}\text { Potential contributions } \\
\text { from business network } \\
\text { literature to GVC analysis }\end{array}$ \\
\hline 1 & $\begin{array}{l}\text { Dynamics of dyadic interfirm } \\
\text { relationships, based on } \\
\text { contrasts between economic } \\
\text { arguments (TCT) and } \\
\text { alternative explanations (e.g. } \\
\text { trust, organizational learning) }\end{array}$ & $\begin{array}{l}\text { Impacts of firms } \\
\text { on dyadic partners }\end{array}$ & $\begin{array}{c}\text { Governance as coordination } \\
\text { of dyads (Gereffi et al., 2005), } \\
\text { combining TCT arguments with } \\
\text { production networks, capabilities, } \\
\text { and firm-level learning }\end{array}$ & $\begin{array}{l}\text { Incorporates organizational } \\
\text { and cognitive lenses in the } \\
\text { study of knowledge and } \\
\text { capability transfer in trust- } \\
\text { based GVCs }\end{array}$ \\
\hline 2 & $\begin{array}{l}\text { Impact of network's attributes } \\
\text { on individual firms, building } \\
\text { on the relational and structural } \\
\text { aspects of embeddedness }\end{array}$ & $\begin{array}{c}\text { Impacts of } \\
\text { network on } \\
\text { individual firms }\end{array}$ & $\begin{array}{l}\text { Not about governance, but can be } \\
\text { related to its associated concept, } \\
\text { GVC upgrading }\end{array}$ & $\begin{array}{l}\text { Uses the idea of firms' } \\
\text { embeddedness in the } \\
\text { network to unveil new } \\
\text { relationships between } \\
\text { governance and upgrading }\end{array}$ \\
\hline 3 & $\begin{array}{l}\text { Dynamics of alliance } \\
\text { formation and development, } \\
\text { with a focus on their } \\
\text { embeddedness in social } \\
\text { networks }\end{array}$ & $\begin{array}{l}\text { Effects of networks } \\
\text { on alliances or } \\
\text { alliance networks }\end{array}$ & $\begin{array}{l}\text { Governance as normalizing } \\
\text { (Ponte \& Gibbon, 2005; } \\
\text { Ponte \& Sturgeon, 2014), } \\
\text { based on Convention Theory } \\
\text { and arguments close to Neo- } \\
\text { Institutional Economics }\end{array}$ & $\begin{array}{l}\text { Explains the evolution } \\
\text { of the norms of GVC } \\
\text { governance under the } \\
\text { action of the various chain } \\
\text { members }\end{array}$ \\
\hline \multirow[t]{2}{*}{4} & \multirow[t]{2}{*}{$\begin{array}{l}\text { Competitive advantage as } \\
\text { given by the tenets of RBV } \\
\text { and KBV }\end{array}$} & $\begin{array}{l}\text { Impacts of hub } \\
\text { firms on their } \\
\text { networks }\end{array}$ & $\begin{array}{l}\text { Governance as driving chains and } \\
\text { networks (Gereffi, 1994), based } \\
\text { on the empirical relevance of } \\
\text { capabilities }\end{array}$ & \multirow[t]{2}{*}{$\begin{array}{l}\text { Makes explicit the } \\
\text { dynamics of power } \\
\text { imbalances included in } \\
\text { GVC governance }\end{array}$} \\
\hline & & $\begin{array}{l}\text { Impacts of firms } \\
\text { on dyadic partners }\end{array}$ & $\begin{array}{c}\text { Governance as coordination } \\
\text { of dyads (Gereffi et al., 2005), } \\
\text { combining TCT arguments with } \\
\text { production networks, capabilities, } \\
\text { and firm-level learning }\end{array}$ & \\
\hline
\end{tabular}

Cluster 2 can be related to research interested in the impact of networks on individual firms, which reflects the scope of cell 2 of Table 1. This empirical scope does not exactly concern governance, but can be related to its associated concept - GVC upgrading (Table 2). In fact, the research represented by Cluster 2 derives from Granovetter's (1985) concept of embeddedness, exploring its enabling and constraining consequences for firm behavior and performance (Rowley et al., 2000; Uzzi, 1996, 1997). Cluster 2's perspective puts the firm that experiences the influence of the network at center stage, which can also be observed, for instance, in research on the upgrading outcomes of networklevel regulatory frameworks and norms for value chain actors (Barrientos \& Smith, 2007; Nadvi, 2008). Beyond such similarities, the concept of embeddedness could expand the upgrading approaches adopted in the GVC literature by highlighting the double-edged role of network participation: while embeddedness can be critical for achieving superior performance in interfirm exchanges, too much embeddedness may induce vulnerability and constrain the action paths accessible to firms (Uzzi, 1997). In GVC theory, this means that upgrading opportunities may not only vary according to different forms of governance, but also according to the strength of the relationships between chain members.

Research related to Cluster 3, in turn, investigates dynamics mostly at the level of 
alliances and alliance networks, which appears in the scope of cell 3 of Table 1. According to Table 2 , the parallel to this cluster can be found in the empirical focus of "governance as normalizing" (Ponte \& Gibbon, 2005; Ponte \& Sturgeon, 2014), but this takes a different theoretical viewpoint. "Governance as normalizing" assumes that networks operate according to efficient coordination mechanisms, whose validity is socially legitimized (Ponte \& Gibbon, 2005). Comparatively, Cluster 3 highlights the dynamic nature of network relationships based on their embeddedness in social contexts (Gulati, 1995b, 1998)which has primarily considered alliances as dyadic exchanges and paid less attention to the fact that key precursors, processes, and outcomes associated with alliances can be defined and shaped in important ways by the social networks within which most firms are embedded. It identifies five key issues for the study of alliances: ( 1 and knowledge-intensive industries (Powell et al., 1996). According to the theories in Cluster 3, network alliances will be forged and evolve when they become instrumental solutions for firms' activities, not only when they become institutionalized. This view extends the governance perspective advanced by Ponte and Sturgeon (2014), who foresaw that the norms of GVC governance "also evolve, are subjected to testing, and are adjusted or give way to different conventions or combinations over time" (p. 210), but never explored how such evolution happens. According to Gulati (1998, p. 306) which has primarily considered alliances as dyadic exchanges and paid less attention to the fact that key precursors, processes, and outcomes associated with alliances can be defined and shaped in important ways by the social networks within which most firms are embedded. It identifies five key issues for the study of alliances: (1, networks are evolutionary products of their ties, exhibiting an endogenous dynamic "between embedded organizational action and the network structure that guides but is also transformed by that action". These evolutionary processes develop according to the amount of information that becomes available about network partners, as well as variations in the content of such information (ibid). Therefore, bridging the topics featured in Cluster 3 and "governance as normalizing" allows for dynamism to be injected into the norms of GVC governance, revealing for instance how they evolve and are transformed by the action of the various chain members.

Cluster 4 does not seem to exhibit a strong connection with network research, but features a competitive discourse that is weaker in Clusters 1 to 3. Therefore, it is reasonable to assume its pertinence to debates that have firmlevel information as an input, which connects it to the scopes of both cell 1 (firms' impacts on other firms) and cell 4 of Table 1 (hub firms' impacts on their networks). In the first case, the parallel with cell 1 brings Cluster 4 closer to Gereffi's (1994) "governance as driving": this author's discussion of the contextual relevance of lead firms' capabilities could be easily related to the RBV and KBV backgrounds of Cluster 4, considering the roles of resources and knowledge in shaping power dependence in interfirm relationships (Huxham \& Beech, 2008). Capabilities and learning also play a relevant role in Gereffi et al.'s (2005) typology of "governance as coordination", giving rise to the dynamics behind the functional division that lead firms project on their chains. Although GVC governance was born in close connection with the concept of power, the origins and distribution of such power were never fully explained (Ponte \& Sturgeon, 2014). In fact, most of the time power distribution in value chains remains unchanged as part of implicit arguments of GVC research (Pananond, 2016). To this extent, the research in Cluster 4 may support discussions of the power imbalances that are implicit in the governance of GVCs.

\section{Concluding Remarks}

In this paper, we focused on how business network research can be used to advance research on GVCs in general and on GVC governance 
in particular. When exploring this issue, we first acknowledged that the connections suggested in Table 2 provide a roadmap that allows for different possible lines of discussion. Our bibliometric analysis of the network research in the management and strategy fields outlined the theoretical foundations to explore those connections. It also revealed opportunities for theoretical contributions from the various communities of network research to the different strands of GVC studies, with a focus on GVC governance.

Our paper contributes foremost to bringing the literature on GVCs closer to the research on business networks associated with management and strategy. Such links remain relatively unexplored within the GVC literature and can reveal fruitful research avenues, as discussed recently by Sako and Zylberberg (2017). By better connecting with network research, GVC theory may improve its capacity to cope with modern empirical challenges in which networklevel phenomena are salient, such as in studies of digital economy relationships (Jacobides et al., 2018; Möller \& Halinen, 2017). It can also overcome criticisms and establish smoother connections with alternative network-based frameworks, such as Global Production Networks (e.g., Coe et al., 2008; Henderson et al., 2002; Yeung \& Coe, 2015). Finally, it can communicate better with scholars from mainstream disciplines and find a way into the main management journal outlets (Sako \& Zylberberg, 2015).

Our discussion outlined a research agenda that includes multiple ways of injecting network research into the GVC literature, by delving into each cell of Table 2. It also sets the stage for research opportunities that we did not explore here. For instance, one could use the network research related to Clusters 1 and 4 of Figure 2 to test the validity limits of the chain metaphor explicit in the "driving" and "coordination" views of governance (Table 5). Given the evolution of modern industries towards networked forms and the criticisms of this simplification, comparative studies contrasting outcomes achieved with chain and network frameworks may be necessary to substantiate the viability of sticking to this metaphor.

Finally, our study is not free of limitations. First of all, the assumption of relatedness between co-cited papers is not perfect since there are multiple rationales for citing papers together, including refutation or criticism (Zupic \& Čater, 2015). Also, citation counting might be biased by self-citation or team-citation. These problems nonetheless seem to be "more theoretical than real", as their frequency is not high enough to distort the overall map of an entire knowledge domain (Garfield, 1979, p. 361). Especially with regards to mitigating the first problem, we sought to analyze the role of leading papers inside their clusters by identifying how their theses supported or contrasted with each other. Furthermore, bibliometric analyses cannot avoid some level of subjectivity (Hjørland, 2013). This can be detected in the methodological choices that authors make early in the research process, such as regarding which journals or papers to include in their analyses, and also later in their interpretation of bibliometric findings. The careful selection of the journals to be included in our data collection and the detailed discussion we reported in the methods section address the former problem to some extent, while the use of Provan et al.'s (2007) typology as a frame of reference throughout our analysis helps in partly overcoming the latter issue.

\section{References}

Bair, J. (2005). Global capitalism and commodity chains: Looking back, going forward. Competition \& Change, 9(2), 153-180.

Bair, J. (2008). Analysing global economic organization: Embedded networks and global chains compared. Economy and Society, 37(3), 339-364.

Barney, J. (1991). Firm resources and sustained competitive advantage. Journal of Management, 17(1), 99-120. 
Barrientos, S., \& Smith, S. (2007). Do workers benefit from ethical trade? Assessing codes of labour practice in global production systems. Third World Quarterly, 28(4), 713-729. doi: https://doi.org/10.1080/01436590701336580

Baum, J. A. C., Calabrese, T., \& Silverman, B. S. (2000). Don't go it alone: Alliance network composition and startups' performance in Canadian biotechnology. Strategic Management Journal, 21(3), 267-294.

Bazzoli, L., Kirat, T., \& Villeval, M.-C. (1994). Rules, contract, and institution in the wage-labor relationship: A return to institutionalism? Journal of Economic Issues, 28(4), 1137-1171.

Bonacich, P. (2007). Some unique properties of eigenvector centrality. Social Networks, 29(4), $555-564$.

Borgatti, S. P., \& Foster, P. C. (2003). The network paradigm in organizational research: A review and typology. Journal of Management, 29(6), 991-1013.

Burt, R. S. (1992). Structural holes: The social structure of competition. Cambridge, MA: Harvard University Press.

Coe, N. M., Dicken, P., \& Hess, M. (2008). Global production networks: Realizing the potential. Journal of Economic Geography, 8(3), 271-295.

Cohen, W. M., \& Levinthal, D. A. (1990). Absorptive capacity: A new perspective on learning and innovation. Administrative Science Quarterly, 35(1), 128-152.

Dyer, J. H., \& Singh, H. (1998). The relational view: Cooperative strategy and sources of interorganizational competitive advantage. Academy of Management Review, 23(4), 660-679.

Eck, N. J., van, \& Waltman, L. (2010). Software survey: VOSviewer, a computer program for bibliometric mapping. Scientometrics, 84(2), 523-538. doi: https://doi.org/10.1007/s11192009-0146-3

Eck, N. J., van, \& Waltman, L. (2014). Visualizing bibliometric networks. In Y. Ding, R. Rousseau, \& D. Wolfram (Eds.), Measuring scholarly impact: Methods and practice (pp. 285-320). Cham: Springer.

Eck, N. J., van, Waltman, L., Dekker, R., \& Van Den Berg, J. (2010). A comparison of two techniques for bibliometric mapping: Multidimensional scaling and VOS. Journal of the American Society for Information Science and Technology, 61(12), 2405-2416.

Garfield, E. (1979). Is citation analysis a legitimate evaluation tool? Scientometrics, 1(4), 359-375.

Gereffi, G. (1994). The organization of buyerdriven global commodity chains: How U.S. retailers shape overseas production networks. In G. Gereffi \& M. Korzeniewicz (Eds.), Commodity Chains and Global Capitalism (pp. 95-122). Westport, CT: Praeger.

Gereffi, G. (1999). International trade and industrial upgrading in the apparel commodity chain. Journal of International Economics, 48(1), 37-70.

Gereffi, G. (2014a). A global value chain perspective on industrial policy and develoment in emerging markets. Duke Journal of Comparative \& International Law, 24(433), 433-458.

Gereffi, G. (2014b). Global value chains in a post-Washington consensus world. Review of International Political Economy, 21(1), 9-37.

Gereffi, G., \& Fernandez-Stark, K. (2011). Global value chain analysis: A primer. Durham, North Carolina: Center on Globalization, Governance \& Competitiviness.

Gereffi, G., Humphrey, J., Kaplinsky, R., \& Sturgeon, T. J. (2001). Introduction: 
Globalisation, value chains and development. IDS Bulletin, 32(3), 1-8.

Gereffi, G., Humphrey, J., \& Sturgeon, T. (2005). The governance of global value chains. Review of International Political Economy, 12(1), 78-104.

Gereffi, G., \& Lee, J. (2012). Why the world suddenly cares about global supply chains. Journal of Supply Chain Management, 48(3), 24-32.

Gibbon, P., Bair, J., \& Ponte, S. (2008). Governing global value chains: An introduction. Economy and Society, 37(3), 315-338.

Granovetter, M. (1985). Economic action and social structure: The problem of embeddedness. American Journal of Sociology, 91(3), 481-510.

Gulati, R. (1995a). Does familiarity breed trust? The implications of repeated ties for contractual choice in alliances. Academy of Management Journal, 38(1), 85-112.

Gulati, R. (1995b). Social structure and alliance formation patterns: A longitudinal analysis. Administrative Science Quarterly, 40(4), 619-652.

Gulati, R. (1998). Alliances and Networks. Strategic Management Journal, 19(19), 293-317.

Henderson, J., Dicken, P., Hess, M., Coe, N., \& Yeung, H. W.-C. (2002). Global production networks and the analysis of economic development. Review of International Political Economy, 9(3), 436-464.

Hjørland, B. (2013). Citation analysis: A social and dynamic approach to knowledge organization. Information Processing \& Management, 49(6), 1313-1325.

Humphrey, J., \& Schmitz, H. (2002). How Does Insertion in Global Value Chains Affect Upgrading in Industrial Clusters? Regional Studies, 36(9), 1017-1027.

Huxham, C., \& Beech, N. (2008). Interorganizational power. In S. Cropper, C. Huxham,
M. Ebers, \& P. Smith Ring (Eds.), The Oxford Handbook of Inter-Organizational Relations (pp. 555-579). Oxford : Oxford University Press.

Jacobides, M. G., Cennamo, C., \& Gawer, A. (2018). Towards a theory of ecosystems. Strategic Management Journal, 39(8), 2255-2276.

Kogut. (1988). Joint ventures: Theoretical and empirical perspectives. Strategic Management Journal, 9(4), 319-332.

Kogut, B., \& Zander, U. (1992). Knowledge of the firm combination, capabilities, and the replication of technology. Organization Science, 3(3), 383-397.

Lane, P. J., \& Lubatkin, M. (1998). Relative absorptive capacity and interorganizational learning. Strategic Management Journal, 19(5), 461-477.

Lee, J., \& Gereffi, G. (2015). Global value chains, rising power firms and economic and social upgrading. Critical Perspectives on International Business, 11(3/4), 319-339.

Lima, F. G. S. N. de, \& Campos, L. A. N., Fo. (2009). Mapping the contemporary studies on alliances and strategic networks. Revista Brasileira de Gestão de Negócios, 11(31), 168-182.

Möller, K., \& Halinen, A. (2017). Managing business and innovation networks-From strategic nets to business fields and ecosystems. Industrial Marketing Management, 67, 5-22.

Morrison, A., Pietrobelli, C., \& Rabellotti, R. (2008). Global value chains and technological capabilities: A framework to study learning and innovation in developing countries. Oxford Development Studies, 36(1), 39-58.

Mowery, D. C., Oxley, J. E., \& Silverman, B. S. (1996). Strategic alliances and interfirm knowledge transfer. Strategic Management Journal, 17(S2), 77-91. 
Nadvi, K. (2008). Global standards, global governance and the organization of global value chains. Journal of Economic Geography, 8(3), 323-343. https://doi.org/10.1093/jeg/lbn003

Navas-Alemán, L. (2011). The impact of operating in multiple value chains for upgrading: The case of the Brazilian furniture and footwear industries. World Development, 39(8), 1386-1397.

Nayyar, D. (2003). Globalization and development strategies. In J. F. J. Toye (Ed.), Trade and Development: Directions for the 21st Century (pp. 35-61). Cheltenham, UK: Edward Elgar.

Nelson, R. R., \& Winter, S. G. (1982). An evolutionary theory of economic change. Cambridge, MA: The Belknap Press.

Pananond, P. (2016). From servant to master: Power repositioning of emerging-market companies in global value chains. Asian Business and Management, 15(4), 292-316.

Pfeffer, J., \& Salancik, G. R. (1978). The external control of organizations: A resource dependence perspective. New York, NY: Harper \& Row.

Ponte, S., \& Gibbon, P. (2005). Quality standards, conventions and the governance of global value chains. Economy and Society, 34(1), 1-31.

Ponte, S., \& Sturgeon, T. (2014). Explaining governance in global value chains: A modular theory-building effort. Review of International Political Economy, 21(1), 195-223.

Powell, W., Koput, K., \& Smith-Doerr, L. (1996). Interorganizational collaboration and the locus of innovation: networks of learning in biotechnology. Administrative Science Quarterly, 41(1), 116-145.

Provan, K. G., Fish, A., \& Sydow, J. (2007). Interorganizational networks at the network level: A review of the empirical literature on whole networks. Journal of Management, 33(3), 479-516.

Raikes, P., Jensen, M. F., \& Ponte, S. (2000). Global commodity chain analysis and the French filière approach: Comparison and critique. Economy and Society, 29(3), 390-417.

Rowley, T., Behrens, D., \& Krackhardt, D. (2000). Redundant governance structures: An analysis of structural and relational embeddedness in the steel and semiconductor industries. Strategic Management Journal, 21(3), 369-386.

Sako, M., \& Zylberberg, E. (2015). From governance to strategy: Injecting Management Studies into Global Value Chains. Working Paper, 1-45. Retrieved from https://papers.ssrn.com/ sol3/papers.cfm?abstract_id=2630066

Sako, M., \& Zylberberg, E. (2017). Supplier strategy in global value chains: shaping governance and profiting from upgrading. Socio-Economic Review, in press, 1-21.

Salancik, G. R. (1995). Wanted: A good network theory of organization. Administrative Science Quarterly, 40(2), 350.

Small, H. (1999). Visualizing science by citation mapping. Journal of the American Society for Information Science, 50(9), 799-813.

Sturgeon, T. (2001). How do we define value chains and production networks? IDS Bulletin, 32(3), 9-18.

Sturgeon, T. (2009). From commodity chains to value chains: Interdisciplinary theory building in an age of globalization. In J. Bair (Ed.), Frontiers ofCommodity Chain Research (pp. 110-135). Palo Alto, CA: Stanford University Press.

Sturgeon, T., Biesebroeck, J., van \& Gereff, G. (2008). Value chains, networks and clusters: Reframing the global automotive industry. Journal of Economic Geography, 8(3), 297-321. 
Szulanski, G. (1996). Exploring internal stickiness: Impediments to the transfer of best practice within the firm. Strategic Management Journal, 17(S2), 27-43.

Todeva, E., \& Knoke, D. (2005). Strategic alliances and models of collaboration. Management Decision, 43(1), 123-148.

Uzzi, B. (1996). The sources and consequences of embeddedness for the economic Performance of organizations: The network effect. American Sociological Review, 61(4), 674-698.

Uzzi, B. (1997). Social structure and competition in interfirm networks: The paradox of embeddedness. Administrative Science Quarterly, 42(1), 35-67.

Waltman, L., Eck, N. J., van, \& Noyons, E. C. M. (2010). A unified approach to mapping and clustering of bibliometric networks. Journal of Informetrics, 4(4), 629-635.
Williamson, O. E. (1985). The economic institutions of capitalism: Firms, markets, relational contracting. New York: Free Press.

Yan, E., \& Ding, Y. (2009). Applying centrality measures to impact analysis: A coauthorship network analysis. Journal of the American Society for Information Science and Technology, 6O(10), 2107-2118.

Yeung, H. W., \& Coe, N. M. (2015). Toward a dynamic theory of global production networks. Economic Geography, 91(1), 29-58.

Zaheer, A., Gözübüyük, R., \& Milanov, H. (2010). It's the connections: The network perspective in interorganizational research. Academy of Management Perspectives, 24(1), 62-77.

Zupic, I., \& Čater, T. (2015). Bibliometric methods in management and organization. Organizational Research Methods, 18(3), 429-472. 
About the Authors:

1. Luis Oliveira, Ph.d., University of São Paulo, São Paulo, Brazil. E-mail: luis.oliveira@usp.br ORCID

(iD 0000-0003-4227-8660

2. Afonso Fleury, Ph.D., University of São Paulo, São Paulo, Brazil. E-mail: acfleury@usp.br

ORCID

(iD)0000-0002-4511-6416

3. Maria Tereza Fleury, Ph.D., University of São Paulo, São Paulo, Brazil. E-mail: mtereza.fleury@fgv.br ORCID

(iD 0000-0002-1570-5164

Has any preliminary version of this article been presented / published in annals of scientific congresses or is it derived from a thesis or dissertation? No

\section{Contribution of each author}

Each author should take responsibility for at least one component of the paper. If the article is approved for publication, the authors should indicate in the diagram below, what was the contribution of each.

\begin{tabular}{lccc}
\hline Contribution & Luis Oliveira & Afonso Fleury & Maria Tereza Fleury \\
\hline 1. Definition of research problem & $\sqrt{ }$ & $\sqrt{ }$ & $\sqrt{ }$ \\
2. Development of hypotheses or research questions (empirical studies) & NA & NA & NA \\
3. Development of theoretical propositions (theoretical work) & $\sqrt{ }$ & $\sqrt{ }$ & $\sqrt{ }$ \\
4. Theoretical foundation/Literature review & $\sqrt{ }$ & $\sqrt{ }$ & NA \\
5. Definition of methodological procedures & $\sqrt{ }$ & $\sqrt{ }$ \\
6. Data collection & NA & $\sqrt{ }$ \\
7. Statistical analysis & & $\sqrt{ }$ \\
8. Analysis and interpretation of data & $\sqrt{ }$ \\
9. Critical revision of the manuscript & & & $\sqrt{ }$ \\
10. Manuscript writing & & & \\
11. Other (please specify which) & & & \\
\hline
\end{tabular}

This information will be available in publications as an end notal in accordance with the criteria, policies and procedures for admission and permanence of scientific journals in SciELO Brazil Collection.

\section{Erratum}

Where was written:

"Review of Business Management, São Paulo, v.21, n.4, p.664-682, oct/dec. 2019”

Now read:

“Rev. Bras. Gest. Neg. São Paulo v.21, Special Issue. 2019 p. 664-682” 